\title{
Art and Science: Combustion via Art
}

\section{Abraham Tamir* \\ Emeritus Professor of Ben-Gurion University of the Negev, Beer-Sheba, Israel}

Submission: April 24, 2018; Published: June 25, 2018

*Corresponding author: Abraham Tamir, Emeritus Professor of Ben-Gurion University of the Negev, Beer-Sheba, Israel, Email: atamir4@012.net.il

\section{Abstract:}

Combustion is the sequence of exothermic chemical reactions between fuel and an oxidant accompanied by the production of heat and conversion of the chemical species to new ones. In the article the combustion process is demonstrated by different artworks where the author believes that the artistic demonstrations of combustion gives to this phenomenon a wider view and it becomes more attractive to the viewer.

Keywords: Combustion; exothermic reaction; burner; artworks; Firepot; Fuel; Physician; Alchemist; Wild spirit; Phlogiston; Oxidation; Rotoflame Camping Cooker; The Fire; Funky Fire; Whaaam; Eruption; Human civilisation

\section{Introduction}

Combustion, burning or fire is the sequence of exothermic chemical reactions between fuel and an oxidant accompanied by the production of heat and conversion of the chemical species to new ones. Combustion supplies most of the energy required by human civilisation where the visible result is fire and flames usually consisting of hot gases and light. The phenomenon of fire is mentioned already in the Bible in Genesis 15:17 as follows:"When the sun had set and darkness had fallen, a smoking firepot with a blazing torch appeared and passes between the pieces." Probably the earliest reasonably scientific attempt to explain combustion was that of Johannes Baptista van Helmont [1], a Flemish physician and alchemist. He observed

the relationship among a burning material, smoke and flame and said that combustion involved the escape of a "wild spirit" from the burning material. In 1667 Johann Joachim Becher [2], a German alchemist and physician, proposed the phlogiston theory. According to it there exist fire-like elements called "phlogiston" that is contained within combustible bodies and are released during combustion. The theory was an attempt to explain processes such as combustion and the rusting of metals, which are now understood as oxidation. It was the great French chemist Antoine Laurent Lavoisier [3] who rejected traditional thinking and framed a new definition of combustion that was widely accepted. Combustion, he said, is the process by which some material combines with oxygen.

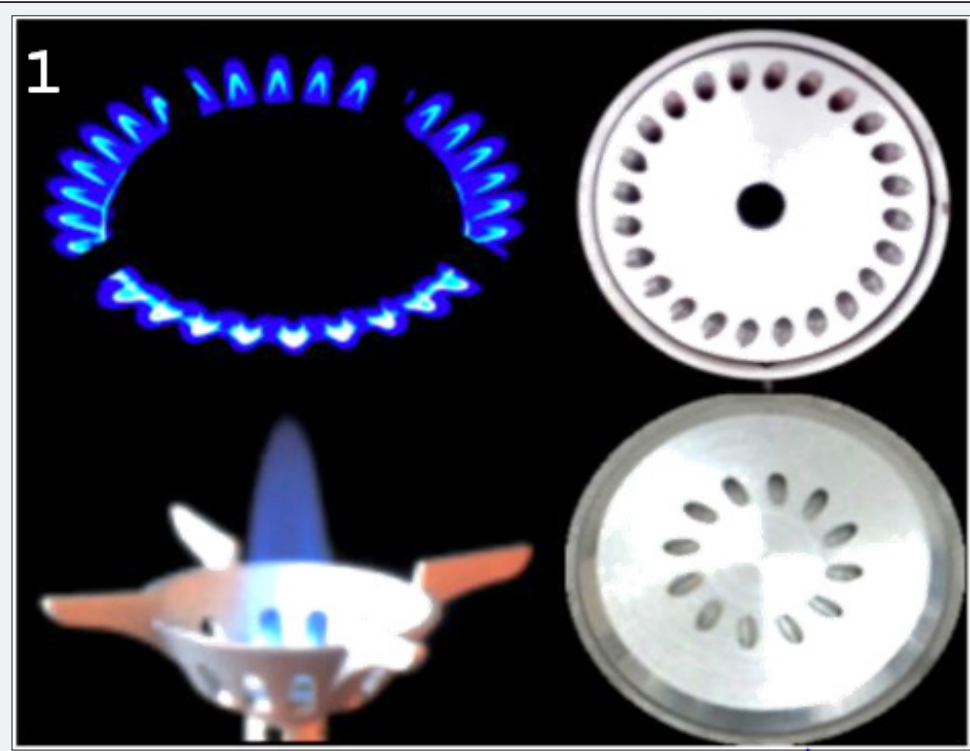

Figure 1: Practical application of combustion to burners used in domestic and outdoors gas stoves. 


\section{Global Journal of Archaeology \& Anthropology}

In the following combustion is presented via artworks. Figure 1 demonstrates practical application of combustion to burners used in domestic and outdoors gas stoves. The regular burner and its flame are shown on the top of the figure. Due to the arrangement of the holes in the burner that are turning outside, the flame is also turning outside. In 1990 the author developed an efficient gas burner in which the holes are turning to the centre of the burner and are located at some angle with respect to the radius of the burner. In this year, the largest manufacturer of camping equipment in Israel launched the market with a new product, the Rotoflame Camping Cooker.

The burner and its flame are shown at the bottom of (Figure 1) where its flame is concentrated and rotating. The stove based on it has the following characteristics:

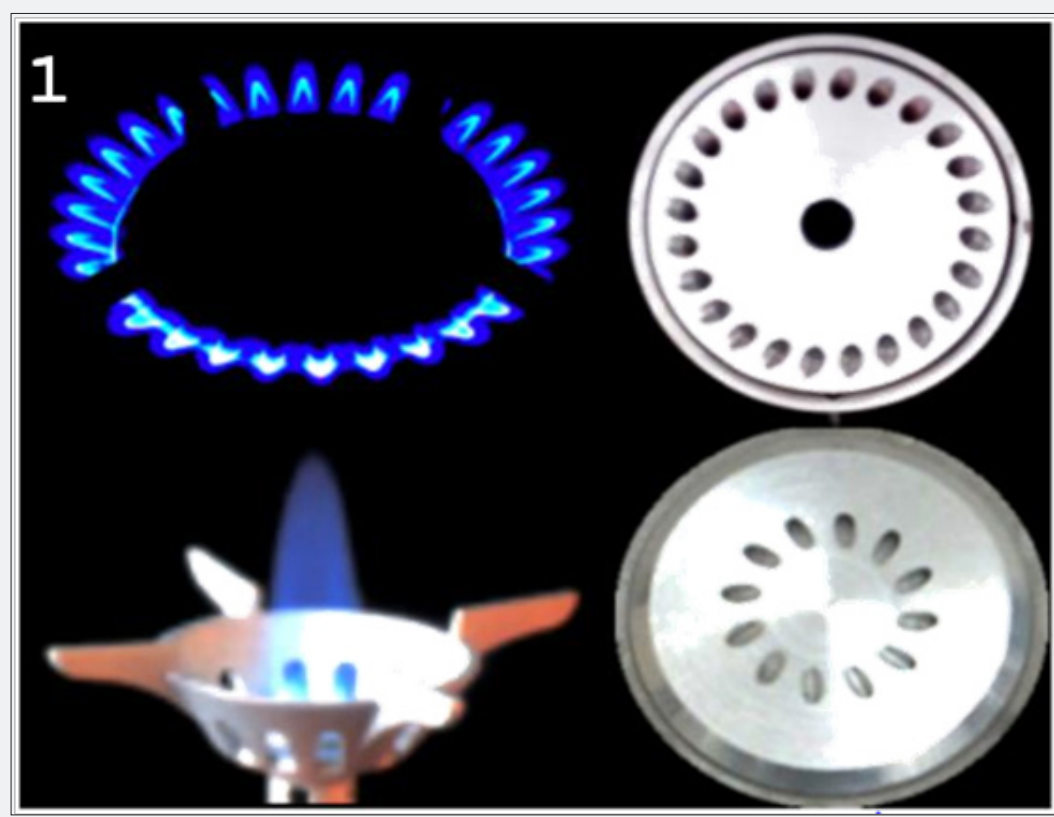

Figure 1: Practical application of combustion to burners used in domestic and outdoors gas stoves.

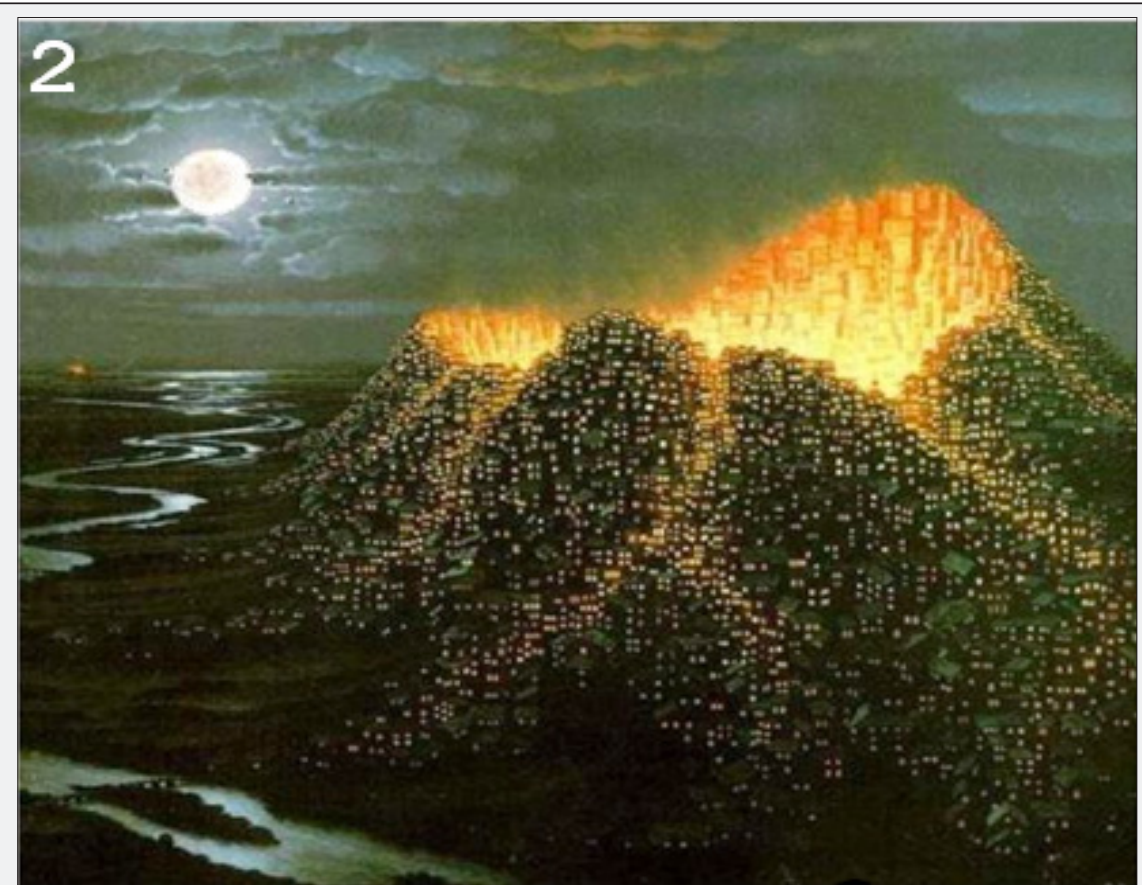

Figure 2: Eruption.

1) Thermal efficiency is higher by $20-25 \%$ than regular burners. 2) Boiling of water is accelerated considerably. 3) Due to rotation of the flame, mixing with air is better, thus reducing air pollution. The Polish surrealist artist Jaceck Yerka [4] painted Figure 2 entitled "Eruption" that demonstrates combustion inside a big hole of a mountain. The Belgium surrealist artist Rene 


\section{Global Journal of Archaeology \& Anthropology}

Magritte (1898-1967) painted Figure 3 entitled "The Discovery of Fire" and Figure 4 (right-hand-side) entitled "Portrait of Edward James". In order to emphasise the effect of combustion in artwork the authors changed the colour from yellow to red in Figure 4 (left-hand-side).
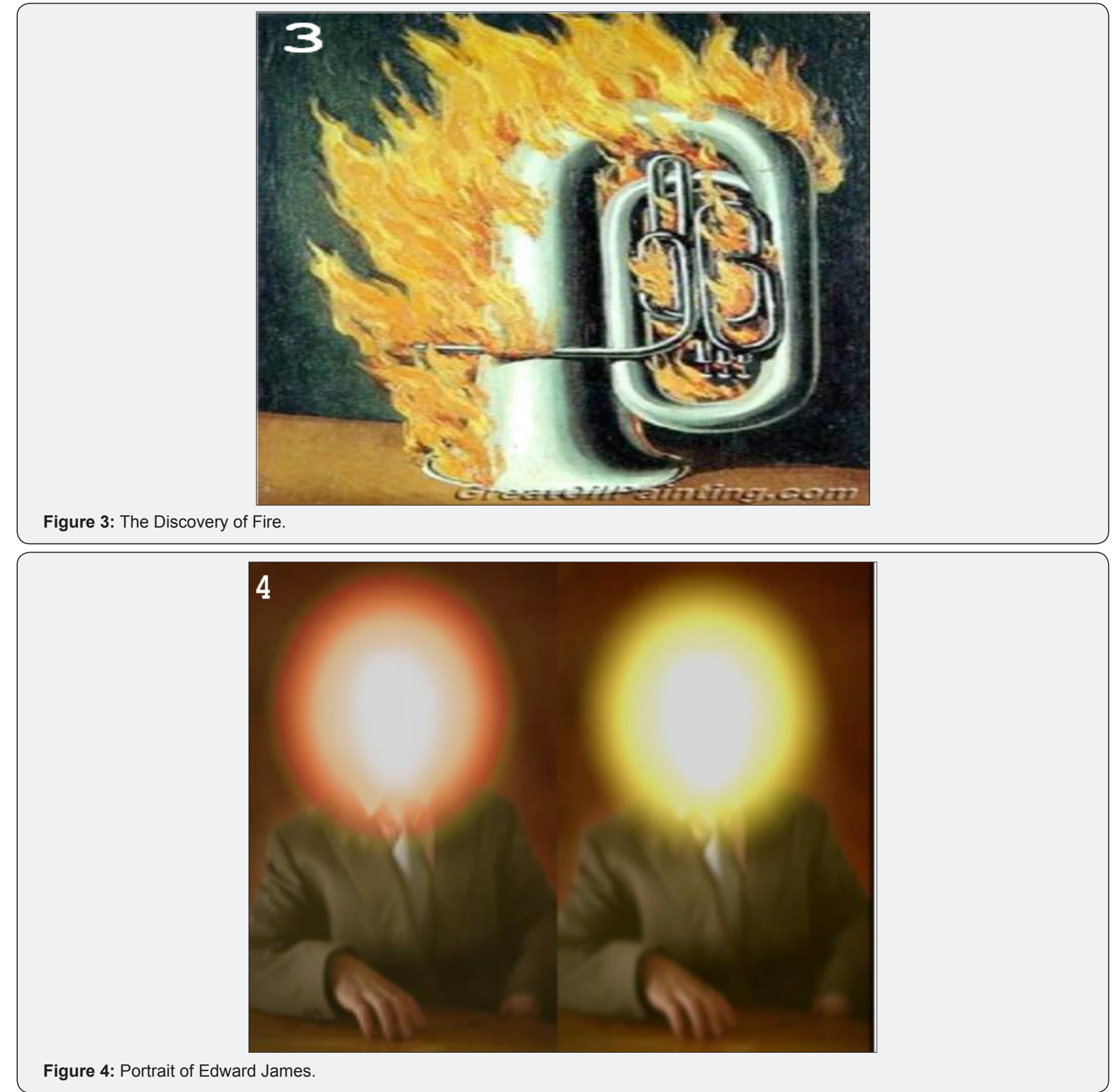

Figure 5 is a surrealistic artwork, "The Fire", painted by Giuseppe Arcimboldo [5], Mannerism Italian painter. Figure 6 entitled "Whaaam" demonstrates combustion due to firing of the enemy by an aircraft. Roy Lichtenstein, an American pop artist, painted it. Rudolph Ackerman an Anglo-German bookseller, inventor and lithographer painted Figure 7 entitled "Fire in London". Figure 8 entitled "Funky Fire" demonstrates a surrealistic fire giving an impression of a terrible combustion. Figure 9 demonstrates a surrealistic "Atomic Bomb Tree" artwork associated with fire. Figure 10 is another surrealistic artwork of fire entitled "Sacred Fire of Pele, Goddess of Hawaii Volcano" that is located in the Hawaiian Art Gallery by Olga Schevchenko [6]. In Figure 11 an interesting surrealistic folding fire is presented where our demonstrations are terminated in Figure 12 by the impressive artwork of Magritte entitled "The Gradation of Fire". In conclusion the author believes that the artistic demonstrations of combustion gives to this phenomenon a wider view and it becomes more attractive to the viewer. 


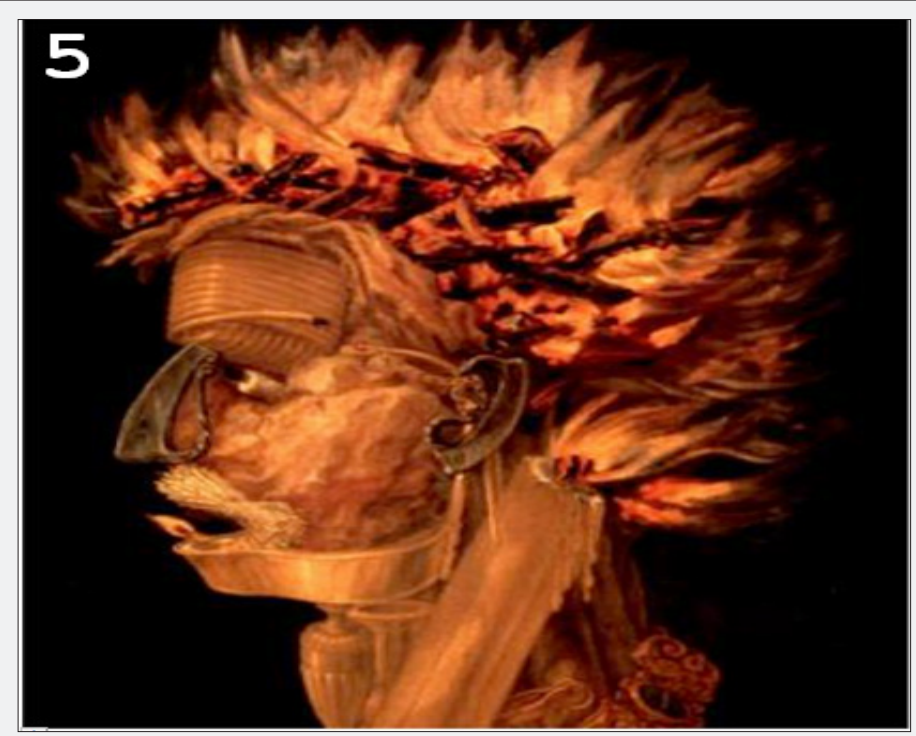

Figure 5: The Fire.

Figure 6: Whaaam.
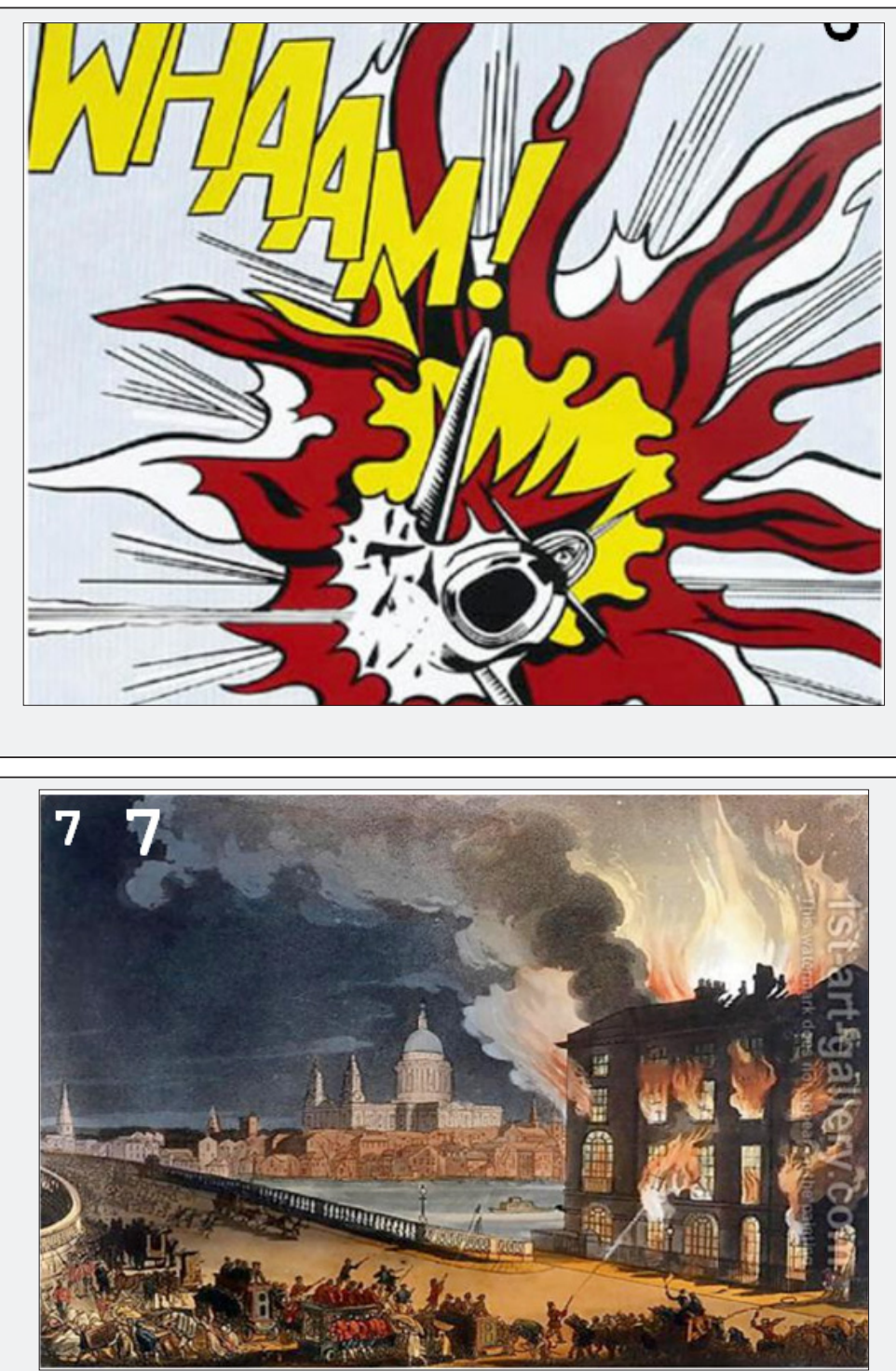

Figure 7: Fire in London. 


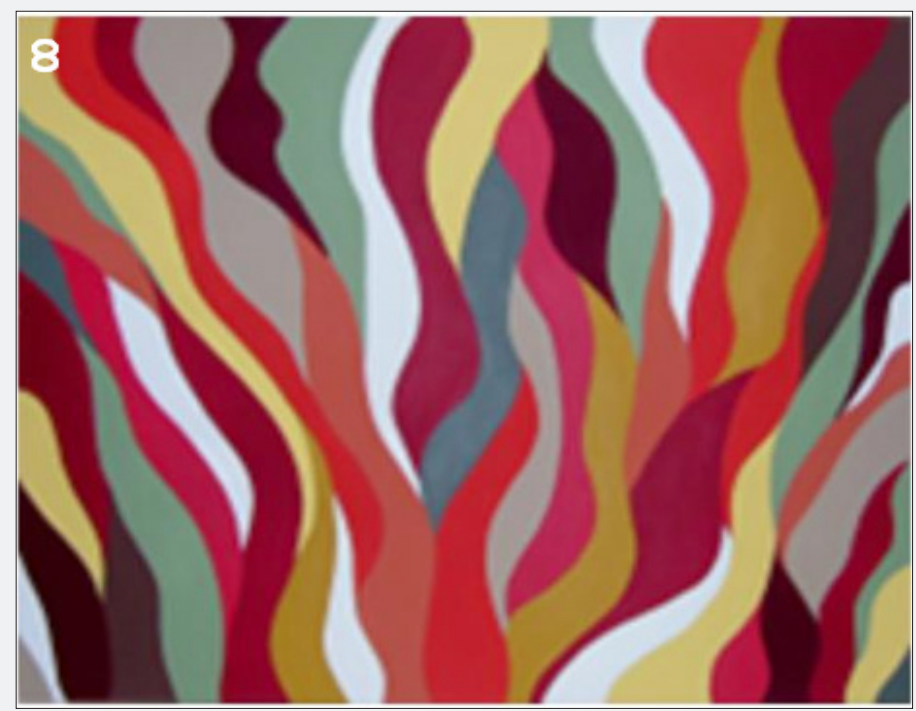

Figure 8: Funky Fire.

Figure 9: Funky Fire.
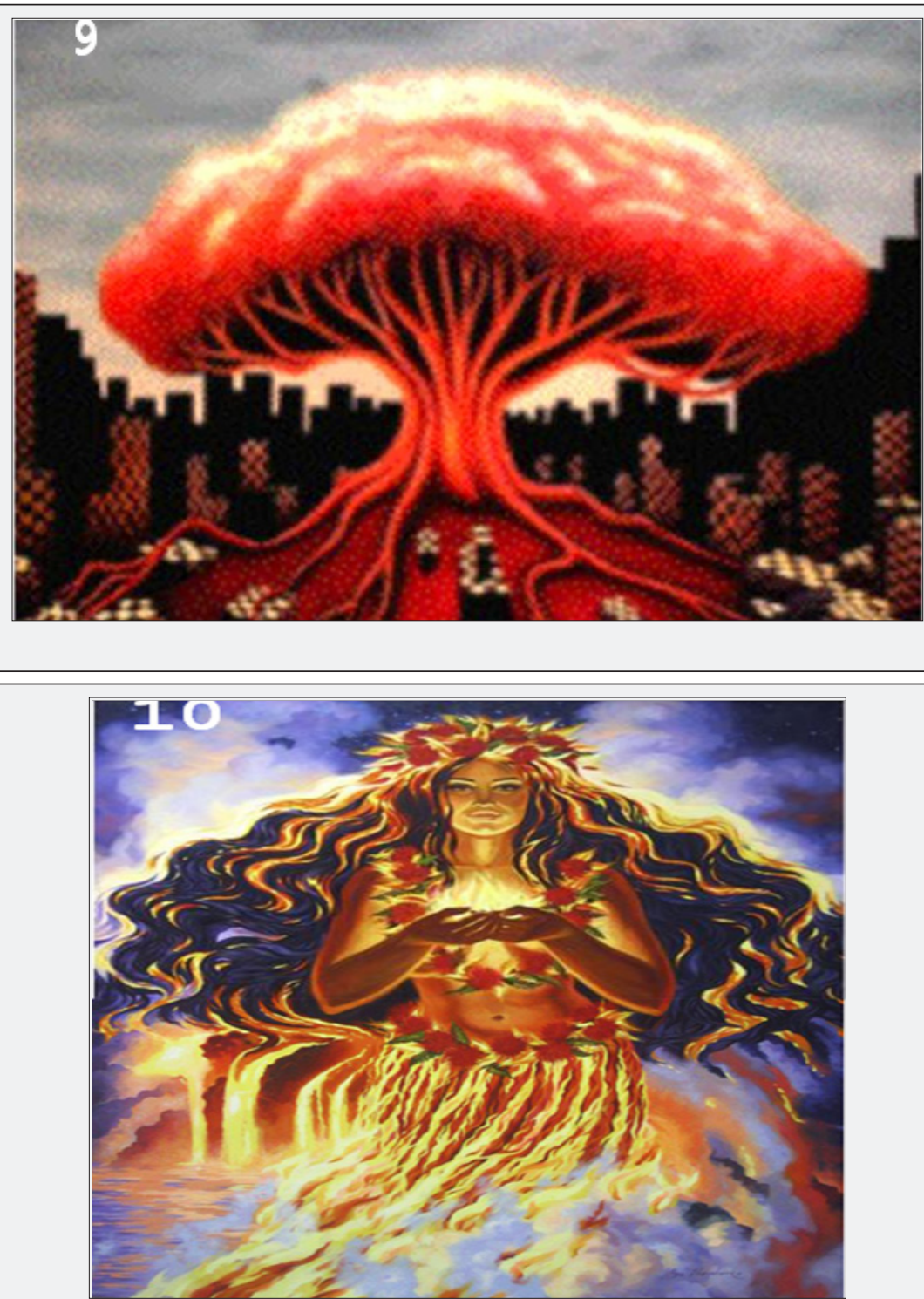

Figure 10 : Sacred Fire of Pele, Goddess of Hawaii Volcano. 


\section{Global Journal of Archaeology \& Anthropology}

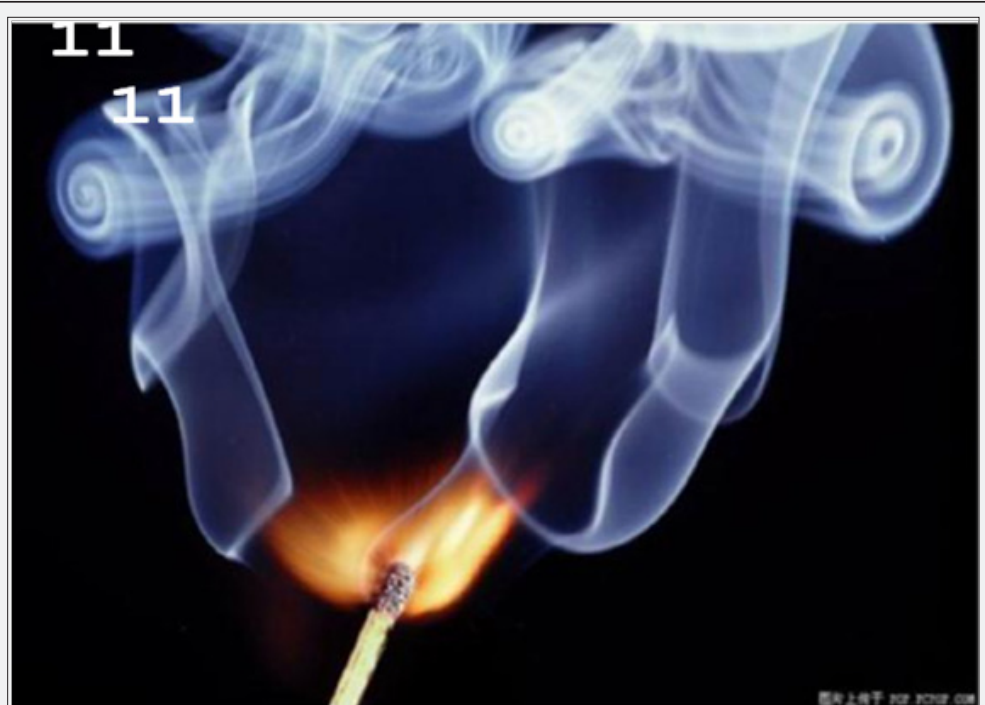

Figure 11 : Surrealistic folding fire.

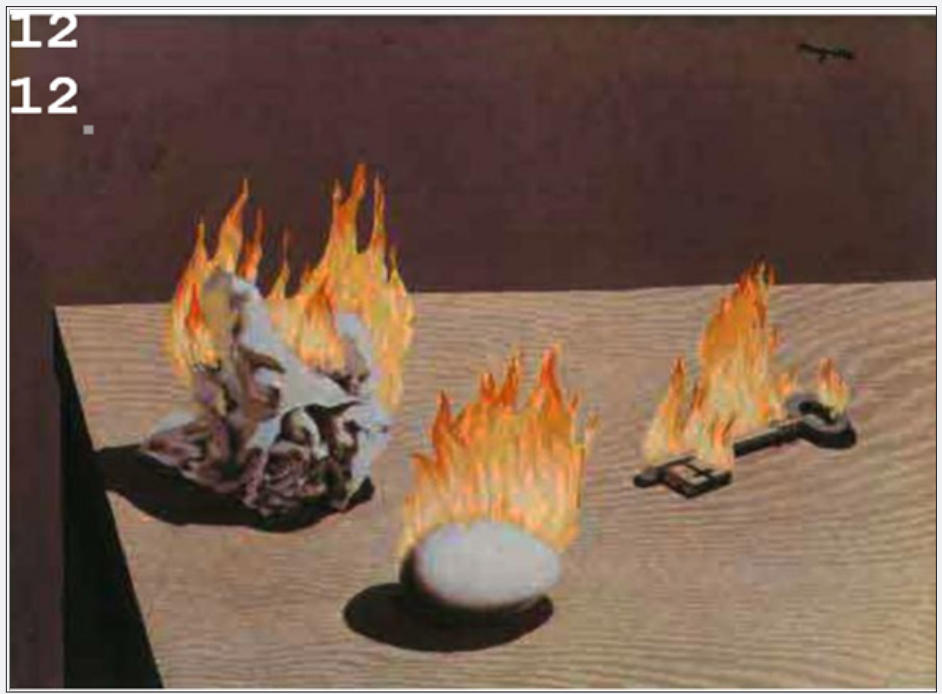

Figure 12 : The Gradation of Fire.

\section{References}

1. Jan Baptist van Helmont (1644) Early life and education.

2. Johann Joachim Becher (1682) Leben. London, UK.

3. Antoine Lavoisier (1794) Early scientific work. Lavoisier, Paris, France.
4. Jacek Yerka (1952) Life in the Academy. Poland, Europe.

5. Giuseppe Arcimboldo (1593) Mannerism: Art heritage, estimates. USA.

6. https://en.wikipedia.org/wiki/Olga_Shevchenko. 


\section{Your next submission with Juniper Publishers} will reach you the below assets

- Quality Editorial service

- Swift Peer Review

- Reprints availability

- E-prints Service

- Manuscript Podcast for convenient understanding

- Global attainment for your research

- Manuscript accessibility in different formats

( Pdf, E-pub, Full Text, Audio)

- Unceasing customer service

Track the below URL for one-step submission https://juniperpublishers.com/online-submission.php 